\title{
KEADILAN DALAM PERSPEKTIF FILSAFAT HUKUM TERHADAP MASYARAKAT
}

\author{
Subhan Amin* \\ E-mail: subhan@gmail.com
}

\begin{abstract}
Abstrak
Hukum mempunyai relevansi yang erat dengan keadilan. Bahkan ada orang yang berpandangan bahwa hukum harus digabungkan dengan keadilan, supaya sungguh-sungguh berarti sebagai hukum. Hal ini terkait dengan tanggapan bahwa hukum merupakan bagian usaha manusia menciptakan suatu ko-eksistensi etis di dunia. Hanya melalui suatu tata hukum yang adil orang dapat hidup dengan damai menuju kebahagiaan, Karena hakikat hukum adalah membawa aturan yang adil dalam masyarakat. Hukum harus mengadakan peraturan yang adil tentang kehidupan masyarakat, sebagaimana dicita-citakan dalam hukum dan hukum mengandung suatu tuntutan keadilan yang diharapkan seluruh ketentuan yang mengatur segala perilaku atau keadaan manusia dalam kehidupan mencerminkan rasa keadilan.
\end{abstract}

Kata Kunci: Keadilan, Filsafat Hukum, Masyarakat

\section{Pendahuluan}

Perbincangan tentang keadilan rasanya merupakan suatu kewajiban ketika berbicara tentang filsafat hukum, mengingat salah satu tujuan hukum adalah keadilan dan ini merupakan salah satu tujuan hukum yang paling banyak dibicarakan sepanjang perjalanan sejarah filsafat hukum. Memahami pengertian keadilan memang tidak begitu sulit karena terdapat beberapa perumusan sederhana yang dapat menjawab tentang pengertian keadilan. Namun untuk memahami tentang makna keadilan tidaklah semudah membaca teks pengertian tentang keadilan yang diberikan oleh para pakar, karena ketika berbicara tentang makna berarti sudah bergerak dalam tataran filosofis yang perlu perenungan secara mendalam sampai pada hakikat yang paling dalam. Pengadilan tidak hanya sebagai badan yang memeriksa dan mengadili perkara melainkan masuk dalam pengertian abstrak juga yaitu memberikan keadilan. Hal memberikan keadilan yang berkaitan dengan tugas badan pengadilan atau hakim dalam memberi keadilan, yaitu memberikan kepada yang bersangkutankongkritnya kepada yang mohon keadilan - apa yang menjadi haknya atau apa hukumnya. Eksistensi pengadilan sebagai lembaga yang berfungsi menyelenggarakan proses peradilan dalam menerima, memeriksa, dan mengadili sengketa masyarakat, tugastugasnya diwakili oleh hakim. Oleh karena itu, kepercayaan masyarakat 
terhadap hukum serta institusi peradilan di negara ini ditentukan oleh kredibilitas dan dan profesionalitas hakim dalam menjalankan tugasnya, menyelesaikan sengketa serta menegakkan keadilan.

\section{A. Teori Keadilan}

Tentang rumusan keadilan ini ada dua pendapat yang dasar yang perlu diperhatikan, sebagai berikut:

a) Pandangan kaum awami (pendapat awam) yang pada dasarnya merumuskan bahwa yang dimaksudkan dengan keadilan itu ialah keserasian antara penggunaan hak dan pelaksanaan kewajiban selaras dengan dalil" neraca hukum "yakni "takaran hak dan kewajiban"

b) Pandangan para ahli hukum (Purnadi Purbacaraka ) yang pada dasarnya merumuskan bahwa keadilan itu adalah keserasian antara kepastian hukum dan kesebandingan hokum. ${ }^{2}$

Teori hukum alam sejak Socrates hingga Francois Geny, tetap mempertahankan keadilan sebagai mahkota hukum. Teori hukum alam mengutamakan "the search for justice". Terdapat macam-macam teori mengenahi keadilan dan masyarakat yang adil. Teoriteori ini menyangkut hak dan kebebasan, peluang kekuasaan, pendapatan dan kemakmuran. Di antara teori-teori tersebut dapat disebut: teori keadilan Aristoteles dalam bukunya nicomachean ethics dan teori keadilan sosial John Rawl dalam bukunya a theory of justice.

Pemikiran Aristoteles mengenai keadilan dapat dipelajari dalam karyanya nichomachean ethics, politics, dan rethoric. Khusus dalam buku nicomachean ethics, sepenuhnya ditujukan bagi keadilan, yang berdasarkan filsafat umum Aristoteles, mesti dianggap sebagai inti dari filsafat hukumnya, "karena hukum hanya bisa ditetapkan dalam kaitannya dengan keadilan".Yang sangat urgen dari pemikirannya adalah pendapat bahwa keadilan mesti dipahami dalam pengertian kesamaan. Namun Aristoteles membuat pembedaan penting antara kesamaan numerik dan kesamaan proporsional. Kesamaan numerik mempersamakan setiap manusia sebagai satu unit. Inilah yang sekarang biasa kita pahami tentang kesamaan dan yang kita maksudkan ketika kita mengatakan bahwa semua warga adalah sama di depan hukum. Kesamaan proporsional memberi tiap orang apa yang menjadi haknya sesuai dengan kemampuannya, prestasinya, dan sebagainya.

Aristoteles menekankan perlunya dilakukan pembedaan antara vonis yang mendasarkan keadilan pada sifat kasus dan yang didasarkan pada watak manusia 
yang umum dan lazim, dengan vonis yang berlandaskan pandangan tertentu dari komunitas hukum tertentu. Pembedaan ini jangan dicampuradukkan dengan pembedaan antara hukum positif yang ditetapkan dalam undang-undang dan hukum adat. Karena, berdasarkan pembedaan Aristoteles, dua penilaian yang terakhir itu dapat menjadi sumber pertimbangan yang hanya mengacu pada komunitas tertentu, sedangkan keputusan serupa yang lain, kendati diwujudkan dalam bentuk perundang-undangan, tetap merupakan hukum alam jika bisa didapatkan dari fitrah umum manusia

Sedangkan keadilan menurut John Rawls, bahwa teori mengenai prinsipprinsip keadilan terutama sebagai alternatif bagi teori utilitarisme. Rawls berpendapat bahwa dalam masyarakat yang diatur menurut prinsip-prinsip utilitarisme, orang-orang akan kehilangan harga diri, lagi pula bahwa pelayanan demi perkembangan bersama akan lenyap. Rawls juga berpendapat bahwa sebenarnya teori ini lebih keras dari apa yang dianggap normal oleh masyarakat. Memang boleh jadi diminta pengorbanan demi kepentingan umum, tetapi tidak dapat dibenarkan bahwa pengorbanan ini pertama-tama diminta dari orang-orang yang sudah kurang beruntung dalam masyarakat.

Situasi ketidaksamaan harus diberikan aturan yang sedemikian rupa sehingga paling menguntungkan golongan masyarakat yang paling lemah dan masyarakat yang kuat. Hal ini terjadi kalau dua syarat dipenuhi. Pertama, situasi ketidaksamaan menjamin maximum minimorum bagi golongan orang yang paling lemah. Artinya situasi masyarakat harus sedemikian rupa sehingga dihasilkan untung yang paling tinggi yang mungkin dihasilkan bagi golongan orang-orang kecil. Kedua, ketidaksamaan diikat pada jabatan-jabatan yang terbuka bagi semua orang. Maksudnya supaya kepada semua orang diberikan peluang yang sama besar dalam hidup. Berdasarkan pedoman ini semua perbedaan antara orang berdasarkan ras, kulit, agama dan perbedaan lain yang bersifat primordial, harus ditolak.

Lebih lanjut John Rawls menegaskan bahwa maka program penegakan keadilan yang berdimensi kerakyatan haruslah memperhatikan dua prinsip keadilan, yaitu, pertama, memberi hak dan kesempatan yang sama atas kebebasan dasar yang paling luas seluas kebebasan yang sama bagi setiap orang. Kedua, mampu mengatur kembali kesenjangan 
sosial ekonomi yang terjadi sehingga dapat memberi keuntungan yang bersifat timbal balik (reciprocal benefits) bagi masyarakat, baik mereka yang berasal dari kelompok beruntung maupun tidak beruntung.

Persoalan keadilan juga menjadi bahasan dalam ranah filsafat hukum Islam, yang biasa disebut teori maslahat. Kajian tentang maslahat sering kali dibahas tatkala berbicara tentang maqasyid syari'ah. Konsep maqasyid syari'ah adalah untuk mewujudkan kebaikan sekaligus menghindarkan keburukan atau menarik manfaat dan menolak mudarat. Maqasyid syari'ah menegaskan bahwa hukum Islam disyariatkan untuk mewujudkan dan memelihara maslahat umat manusia. Istilah yang sepadan dengan inti dari maqasyid syari'ah adalah maslahat, karena penetapan hukum dalam Islam harus bermuara kepada maslahat. Konsep maslahat yang popular dan menjadi prioritas yaitu memelihara agama, jiwa, akal, keturunan dan harta.

Bahwa keadilan adalah keserasian antara penggunaan hak dan pelaksanaannya? Adanya kenyataan berdasarkan dalil " takaran hak adalah kewajiban", yang secara jelas berarti seperti berikut ini : a) Hak setiap orang itu besar kecilnya tergantung pada atau selaras dengan besar kecil kewajibannya, sehingga dengan demikian berarti pula seperti dibawah ini.

b) Dalam keadaan yang wajar, tidaklah benar kalau seseorang dapat memperoleh haknya secara tidak selaras dengan kewajibannya atau tidak pula selaras kalau seseorang itu dibebankan kewajiban yang tidak selaras dengan haknya.

c) Tiada seorangpun dapat memperoleh haknya tanpa ia melaksanakan kewajibannya, baik sebelum maupun sesudahnya, dan dengan demikian pula sebaliknya tiada seorangpun yang dapat dibebankan kewajibannya tanpa ia memperoleh haknya, baik sebelum maupun sesudahnya.

Contohnya :

- Setiap pemilik suatu benda atau pemegang hak milik atas suatu benda harus membayar pajak kekayaannya atas benda miliknya itu dalam jumlah tertentu yang ditentukan menurut harga atau nilai bendanya tersebut. semakin mahal harga atau nilai benda tersebut, maka semakin mahal pula pajak yang harus dibayar oleh pemiliknya dan demikian pula sebaliknya. 
- Upah seorang pegawai tentunya diselaraskan dengan berat ringan pekerjaannya. ${ }^{3}$

\section{B. Pandangan Para Filosof Tentang} Keadilan

Plato, menurutnya keadilan hanya dapat ada di dalam hukum dan perundang-undangan yang dibuat oleh para ahli yang khusus memikirkan hal itu. ${ }^{4}$ Untuk istilah keadilan ini Plato menggunakan kata yunani" Dikaiosune" yang berarti lebih luas, yaitu mencakup moralitas individual dan sosial. ${ }^{5}$ Penjelasan tentang tema keadilan diberi ilustrasi dengan pengalaman saudagar kaya bernama Cephalus. Saudagar ini menekankan bahwa keuntungan besar akan didapat jika kita melakukan tindakan tidak berbohong dan curang. Adil menyangkut relasi manusia dengan yang lain. ${ }^{6}$

a) Aristoteles, adalah seorang filosof pertama kali yang merumuskan arti keadilan. Ia mengatakan bahwa keadilan adalah memberikan kepada setiap orang apa yang menjadi haknya, fiat jutitia bereat mundus. ${ }^{7}$ Selanjutnya dia membagi keadilan dibagi menjadi dua bentuk yaitu:
Pertama, keadilan distributif, adalah keadilan yang ditentukan oleh pembuat undang-undang, distribusinya memuat jasa, hak, dan kebaikan bagi anggota-anggota masyarakat menurut prinsip kesamaan proporsional.

Kedua, keadilan korektif, yaitu keadilan yang menjamin, mengawasi dan memelihara distribusi ini melawan serangan-serangan ilegal. Fungsi korektif keadilan pada prinsipnya diatur oleh hakim dan menstabilkan kembali status quo dengan cara mengembalikan milik korban yang bersangkutan atau dengan cara mengganti rugi atas miliknya yang hilang. ${ }^{8}$ Atau kata lainnya keadilan distributif adalah keadilan berdasarkan besarnya jasa yang diberikan, sedangkan keadilan korektif adalah keadilan berdasarkan persamaan hak) Plato, menurutnya keadilan hanya dapat ada di dalam hukum dan perundangundangan yang dibuat oleh para ahli yang khusus memikirkan hal itu. ${ }^{4}$ Untuk istilah keadilan ini Plato menggunakan kata yunani" Dikaiosune" yang berarti lebih luas, yaitu mencakup moralitas individual dan sosial. ${ }^{5}$ Penjelasan tentang tema 
keadilan diberi ilustrasi dengan pengalaman saudagar kaya bernama Cephalus. Saudagar ini menekankan bahwa keuntungan besar akan didapat jika kita melakukan tindakan tidak berbohong dan curang. Adil menyangkut relasi manusia dengan yang lain. ${ }^{6}$

b) Aristoteles, adalah seorang filosof pertama kali yang merumuskan arti keadilan. Ia mengatakan bahwa keadilan adalah memberikan kepada setiap orang apa yang menjadi haknya, fiat jutitia bereat mundus. ${ }^{7}$ Selanjutnya dia membagi keadilan dibagi menjadi dua bentuk yaitu :

Pertama, keadilan distributif, adalah keadilan yang ditentukan oleh pembuat undang-undang, distribusinya memuat jasa, hak, dan kebaikan bagi anggota-anggota masyarakat menurut prinsip kesamaan proporsional.

Kedua, keadilan korektif, yaitu keadilan yang menjamin, mengawasi dan memelihara distribusi ini melawan serangan-serangan ilegal. Fungsi korektif keadilan pada prinsipnya diatur oleh hakim dan menstabilkan kembali status quo dengan cara mengembalikan milik korban yang bersangkutan atau dengan cara mengganti rugi atas miliknya yang hilang. ${ }^{8}$

Atau kata lainnya keadilan distributif adalah keadilan berdasarkan besarnya jasa yang diberikan, sedangkan keadilan korektif adalah keadilan berdasarkan persamaan hak tanpa.melihat besarnya jasa yang diberikan.

c) Ulpianus yang mengatakan bahwa keadilan adalah kemauan yang bersifat tetap dan terus menerus untuk memberikan kepada setiap orang apa yang mestinya untuknya (Iustitia est constans et perpetua voluntas ius suum cuique tribuendi) .

d) Justinian yang menyatakan bahwa "keadilan adalah kebijakan yang memberikan hasil, bahwa setiap orang mendapat apa yang merupakan bagiannya"

e) Herbert Spenser yang me nyatakan bahwa setiap orang bebas untuk menentukan apa yang akan dilakukannya, asal ia tidak melanggar kebebasan yang sama dari lain orang".

f) Roscoe Pound yang melihat indikator keadilan dalam hasil-hasil konkret yang bisa diberikannya kepada masyarakat. Ia melihat bahwa hasil yang diperoleh itu hendaknya berupa perumusan kebutuhan manusia 
sebanyak-banyaknya dengan

pengorbanan yang sekecil-kecilnya.

g) Nelson yang meyatakan bahwa “Tidak ada arti lain bagi keadilan kecuali persamaan pribadi".

h) John Salmond yang menyatakan bahwa norma keadilan menentukan ruang lingkup dari kemerdeka an individual dalam mengejar ke makmuran individual, sehingga dengan demikian membatasi kemerdekaan individu di dalam batas-batas sesuai dengan kesejahteraan umat manusia

i) Hans Kelsen, menurutnya keadilan tentu saja juga digunakan dalam hukum, dari segi kecocokan dengan hukum positif-terutama kecocokan dengan undang-undang. Ia menggangap sesuatu yang adil hanya mengungkapkan nilai kecocokan relative dengan sebuah norma"adil' hanya kata lain dari 'benar". 9

j) Jhon Rawls, Konsep keadilan menurut rawls, ialah suatu upaya untuk mentesiskan paham liberalisme dan sosialisme. Sehingga secara konseptual rawls menjelaskan keadilan sebagai fairness, yang mengandung asas-asas, "bahwa orang-orang yang merdeka dan rasional yang berkehendak untuk mengembangkan

kepentingan-

kepentingannya hendaknya memperoleh suatu kedudukan yang sama pada saat akan memulainya dan itu merupakan syarat yang fundamental bagi mereka untuk memasuki perhimpuan yang mereka hendaki. ${ }^{10}$

\section{Keadilan dalam Perpektif Filsafat Hukum}

a) Penganut paradigma Hukum Alam meyakini bahwa alam semesta diciptakan dengan prinsip keadilan, sehingga dikenal antara lain Stoisisme norma hukum alam primer yg bersifat umum menyatakan:Berikanlah kepada setiap orang apa yang menjadi haknya (unicuique suum tribuere), dan jangan merugikan seseorang (neminem laedere)". Cicero juga menyatakan bahwa hukum dan keadilan tidak ditentuk an oleh pendapat manusia, tetapi oleh alam.

b) Paradigma Positivisme Hukum, keadilan dipandang sebagai tujuan hukum. Hanya saja disadari pula sepenuhnya tentang relativitas dari keadilan ini sering mengaburkan unsur lain yang juga penting, yakni unsur kepastian hukum. Adagium yang selalu didengungkan adalah Suum jus, summa injuria; summa lex, summa crux. 
Secara harfiah ungkapan tersebut berarti bahwa hukum yang keras akan melukai, kecuali keadilan dapat menolongnya.

c) Dalam paradigma hukum

Utiliranianisme, keadilan dilihat secara luas. Ukuran satu-satunya untuk mengukur sesauatu adil atau tidak adalah seberapa besar dampaknya bagi kesejahteraan manusia (human welfare). Adapun apa yang dianggap bermanfaat dan tidak bermanfaat, diukur dengan perspektif ekonomi. ${ }^{11}$

\section{Pandangan Islam tentang Keadilan}

Keadilan menurut pandangan Islam merupakan tonggak kehidupan seseorang yang berhati nurani karena dengan kuatnya standard of Morality, maka akan mampu meletakkan suatu perkara secara proporsional dan terbebas dari keberpihakan atau kepentingan sepihak/golongan. Keadilan tidak dapat dipengaruhi oleh perasaan senang, terpaksa, permusuhan, kedudukan, dan lain-lain. Adil di kacamata Islam adaah salah satu norma yang menunjukkan tingkat ketaqwaan seseorang muslim terhadap ajaran yang diwahyukan oleh Allah SWT ke Nabi Besar Muhammad SAW. ${ }^{12}$

Ukurannya bagi sebutan orang yang adil, masyarakat yang adil dan pemerintah yang adil adalah orang yang mengatakan sebenar-benarnya apa-apa yang dia ketahui karena rasa takut kepada Allah SWT, bukan takut kepada manusia atau jabatan, serta kekuasaan. Jadi ukurannya adalah mengemukakan kebenaran tanpa dipengaruhi oleh apapun kecuali atas nama Allah SWT seperti bunyi firman Allah dalam Surat AnNissaa' (Wanita) yang berbunyi:

"Wahai orang-orang yang beriman: Jadilah kamu orang yang benar-benar penegak keadilan, menjadi saksi karena Allah barpun terhadap kaum kerabatmu, Jika ia (orang yang tergugat atau yang terdakwa) kaya ataupun miskin, maka Allah lebih tahu kemaslahatannya.Maka Janganlah kamu mengikuti hawa nafsu karena ingin menyimpang dari kebenaran. Dan Jika kamu memutar balikkan (kata-kata) atau enggan menjadi saksi, maka sesungguhnya Allah adalah Maha mengetahui segala apa yang kamu kerjakan.

Keharusan menjaga kebenaran dan keadilan juga diatur dalam Surah AnNisaa (Surat ke-4) Ayat 105 yang mengatakan,

"Sesungguhnya kami telah menurunkan kitab kepadamu dengan membawa kebenaran, supaya kamu mengadili antara manusia dengan apa yang telah Allah wahyukan kepadamu, dan janganlah kamu menjadi 
penantang (orang yang tidak bersalah), karena (membela) orang-orang yang khianat"

Masyarakat yang Adil, adalah dimana hukum dijadikan Panglima dalam menjalani kehidupan sehari-hari, dimana interaksi antar manusia sangat kuat terjadi, kemungkinan untuk tidak berlaku adil mungkin saja terjadi, tetapi bila hukum dijadikan panglima dalam kehidupan sehari-hari Insya Allah keadilan akan selalu berada di dalamnya, karena sesuatu yang tidak dapat disangkal ialah adanya hubungan antara hukum dan keadilan. Untuk menegakan keadilan perlu adanya hukum yang bebas dari unsur-unsur negatif. (kekuasaan yang otorirer, dan lain-lain).

Perspektif tentang keadilan sebagaimana dirumuskan di atas, menurut Satjipto Rahardjo, seperti dikutip oleh Angkasa bahwa keadilan mencerminkan bagaimana seseorang melihat tentang hakikat manusia dan bagaimana seseorang memperlakukan manusia. ${ }^{13}$

Lebih lanjut Angkasa mengatakan bahwa Karena keadilan adalah ukuran yang dipakai seseorang dalam memberikan terhadap objek yang berada di luar diri orang tersebut. Mengingat objek yang dinilai adalah manusia maka ukuran-ukuran yang diberikan oleh seseorang terhadap orang lain tidak dapat dilepaskan dengan bagaimana seseorang tersebut memberikan konsep atau makna tentang manusia. Apabila seseorang melihat orang lain sebagai mahluk yang mulia maka perlakuan seseorang tersebutpun akan mengikuti anggapan yang dipakai sebagai ancangan dan sekaligus akan mentukan ukuran yang dipakai dalam menghadapi orang lain. Dengan demikian dapatlah dikatakan bahwa masalah keadilan tidak dapat dilepaskan dengan filsafat tentang manusia. ${ }^{14}$

\section{E. Kesimpulan}

Berdasarkan uraian di atas, dapat diambil kesimpulan sebagai berikut: Pertama, keadilan menurut konsep Aristoteles mesti dipahami dalam pengertian kesamaan, yaitu kesamaan numerik dan kesamaan proporsional. John Rawl menegaskan bahwa program penegakkan keadilan keadilan yang berdimensi kerakyatan haruslah memperhatikan dua prinsip keadilan, yaitu: pertama, memberi hak dan kesempatan yang sama atas kebebasan dasar yang paling luas seluas kebebasan yang sama bagi setiap orang. Kedua, mampu mengatur kembali kesenjangan sosial ekonomi yang terjadi sehingga dapat memberi keuntungan yang bersifat 
timbal balik (reciprocal benefits) bagi setiap orang, baik mereka yang berasal dari kelompok beruntung maupun tidak beruntung. Sedangkan keadilan dalam ranah filsafat hukum Islam masuk dalam bahasan maqasyid syari'ah yang terkonstruk dalam bangunan teori maslahah.

Jadi pemerintahan yang adil adalah pemerintahan yang menjalankan roda pemerintahan dengan memenuhi kewajibannya yang tertuang dalam konstitusi dengan sebaik-baiknya. Artinya pemerintah adalah pelayan masyarakat bukan pemerintah harus dilayani oleh masyarakat. (apabila itu terjadi tunggulah kehancurann pemerintahan tersebut).

Keadilan, Memang tidak semudah membalik telapak tangan bahwa menyatakan suatu pemerintahan atau dalam masyarakat sudah berbuat adil. Untuk menciptakan suatu pemerintahan yang adil sudah pasti akan menuai banyak protes-protes dari berbagai kalangan yang merasa tidak terpenuhi aspirasinya, tetapi yang penting dalam suatu pemerintahan yang adil harus terjadi pembagian kewenangan antara legislatif, eksekutif dan yudikatif. Sehingga terlihat ketiga bagian tersebut berjalan seiring (satu langkah), karena keadilan itu hanya merupakan alat untuk melaksanakan hukum kepada semua orang dengan tidak boleh memandang perbedaan maupun kedudukannya sebagaimana dinyatakan dalam Al-Quran Surat An-Nissa ayat 58 yaitu "Dan apabila menetapkan hukum di antara manusia hendaklah kamu menetapkan dengan adil"

\section{Referensi}

1Friederich, Carl Joachim, Filsafat Hukum Perspektif Historis, Bandung: Nuansa dan Nusamedia, 2004.

2Huijbers, Theo, Filsafat Hukum, Yogyakarta: Kanisius, 1995.

3Manan, Bagir, Wajah Hukum di Era Reformasi, Bandung: Citra Aditya bakti, 2000.

4Mertokusumo, Sudikono, Mengenal Hukum, Yogyakarta: Liberty, 2007.

5Rawl, John, Teori Keadilan, terjemahan Uzair Fauzan dan Heru Prasetyo, Yogyakarta: Pustaka Pelajar, 2006.

6Suparmono, Rudi, Peran Serta Hakim Dalam Pembelajaran Hukum, Varia Peradilan edisi Mei 2006.

7Angkasa, 2010, Filsafat Hukum ( Materi Kuliah ), Magister Ilmu Hukum Hukum UNSOED, Perwokerto, hal.106-

8Ansori, Abdul Gafur, 2006, Filsafat Hukum Sejarah, Aliran Dan Pemaknaan, Gajah Mada Universisty Press, Yogyakarta

9Fuady, Munir Fuady, 2010, Dinamika Teori Hukum, Ghalia Indonesia, Ciawi-Bogor,

10Garvey, James, 2010, 20 Karya Filsafat Terbesar, Penerbit Kanisius, Yogyakarta

11Halim, A. Ridwan, 2005, Pengantar Ilmu Hukum Dalam Tanya Jawab, Ghalia Indonesia, Jakarta,

12Kelsen Hans, 2009, Pengantar Teori Hukum, Penerbit Nusa Media, Bandung,

13Manullang, E. Fernando M, 2007, Menggapai Hukum Berkeadilan, Buku Kompas, Jakarta

14Rato,Dominikus, 2010, Filsafat Hukum, Mencari, Menemukan, Dan Memahami Hukum, LaksBang Yustisia, Surabaya

15Artikel internet; Islam, Universitas, Soal $\mathcal{E}$ Jawaban Filsafat Hukum" .www.blogger.com, 2009 